\title{
The influence of platform switching in dental implants. A literature review
}

\author{
Pedro Serrano-Sánchez ${ }^{1}$, Jose Luis Calvo-Guirado ${ }^{2}$, Ester Manzanera-Pastor ${ }^{3}$, Carmen Lorrio-Castro ${ }^{3}$, \\ Pablo Bretones-López ${ }^{3}$, Juan Antonio Pérez-Llanes ${ }^{3}$
}

\footnotetext{
${ }^{1}$ Dental surgeon. Postgraduate in Medicine and Oral Surgery. Faculty of Medicine and Dentistry, University of Valencia (Valencia, Spain). Postgraduate in dental implants and biomaterials. Faculty of Medicine and Dentistry, University of Murcia (Murcia, Spain) ${ }^{2}$ Senior Lecturer, Adult Integrated Dentistry Clinic and Director of Implantology Masters Program, Faculty of Medicine and Dentistry, the University of Murcia (Murcia, Spain)

${ }^{3}$ Dental surgeon. Postgraduate in dental implants and biomaterials. Faculty of Medicine and Dentistry, University of Murcia (Murcia, Spain)
}

\section{Correspondence:}

Clinica Ochoa,

Calle Llanos de San Ramón, 3, 29600 Marbella (Málaga) Spain, serranosanchez@gmail.com

Received: 20/04/2010 Accepted: 14/11/2010
Serrano-Sánchez P, Calvo-Guirado JL, Manzanera-Pastor E, LorrioCastro C, Bretones-López P, Pérez-Llanes JA. The influence of platform switching in dental implants. A literature review. Med Oral Patol Oral Cir Bucal. 2011 May 1;16 (3):e400-5.

http://www.medicinaoral.com/medoralfree01/v16i3/medoralv16i3p400.pdf

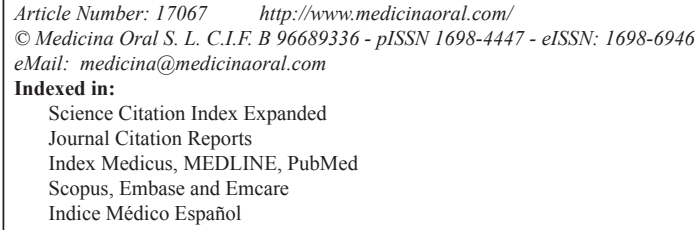

\begin{abstract}
Introduction: The platform switching concept involves the reduction of the restoration abutment diameter with respect to the diameter of the dental implant.

In 1991, dental implants of 5 and $6 \mathrm{~mm}$ diameter platforms were introduced. However, matching-diameter prosthetic abutments were not available. These implants were restored with "standard"-diameter prosthetic components $(4,1 \mathrm{~mm})$.

Long-term follow up around these wide-platforms showed higher levels of bone preservation. In time, it has been called platform switching. The first case report applying this concept was indexed in MedLine in 2005.

Materials and Methods: The aim of this article is to carry out a literature review of articles which deal with the influence of this modified platform in hard and soft oral tissues. All papers involving "platform switching" that are indexed in MedLine and published in English were used. Clinical cases, experimental and non-experimental studies were included, as well as literature reviews.

Results: In our search, we found: 16 clinical series or single clinical cases, 10 test and control studies, 9 experimental studies and 3 reviews.

Conclusion: All papers written by different researchers show an improvement in perimplant bone preservation. Further long-term studies are necessary to confirm these results.

The articles consulted refer to the biomechanical behavior of the abutment-implant complex in response to occlusal loading, the maintenance of crestal bone height and the peculiar repositioning of the biological space.
\end{abstract}

Key words: Platform switching, dental implant, crestal bone preservation. 


\section{Introduction}

Platform switching involves reducing the restoration abutment diameter in comparison with the diameter of the dental implant (1).

In aesthetic areas, the use of dental implants as replacements for lost permanent teeth remains an important challenge due to the difficulty of restoring the natural sulcus and papillary anatomical appearance around the implants. Despite the available technology, in some cases dental implants are unable to achieve optimum esthetic results (2). Correct location of the soft tissues in dental implant restorations depends on the preservation of bone crestal height. Consequently, hard tissues are the principal determinant of aesthetic outcome (2).

The platform switching effect was accidentally established in the 1980s and early 1990s when different commercial dental implant manufacturers introduced implants of larger diameter before producing the corresponding abutments of the same measures. 14 years later, evaluation of those treatments in which abutments of lesser diameter were used revealed better preservation of the hard and soft tissues than treatment that use abutments with diameters matched to the implant $(3,4)$.

In platform switching it is possible to use abutments with a diameter smaller than the implant neck or body width, or alternatively an implant design can be used in which the neck diameter is increased with respect to the implant body width (fig. 1) (5).

Recently, some authors have proposed platform switching using implants with a reverse conical neck. The results obtained with this implant design do not appear to be significantly superior to those obtained with the traditional restoration designs, however $(6,7)$.

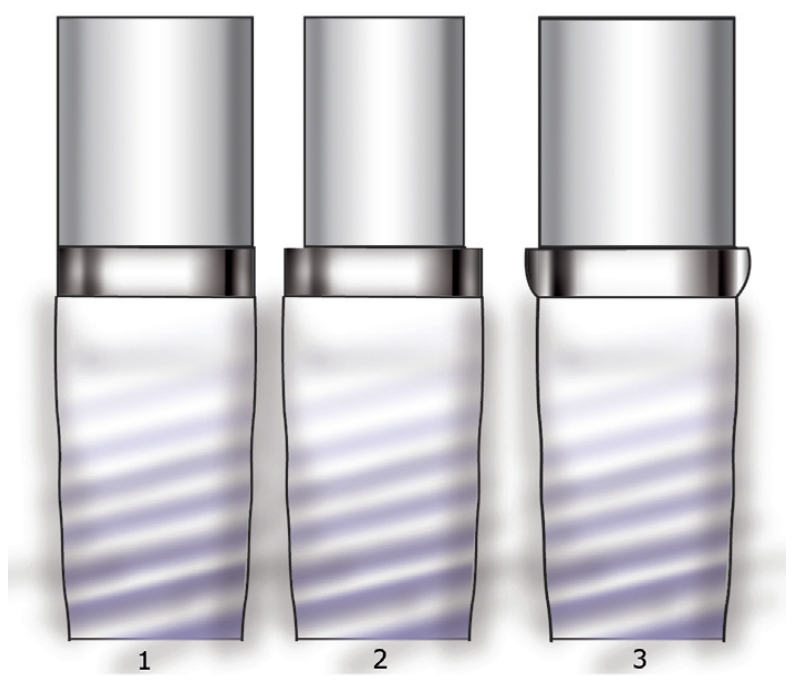

Fig. 1. Implant-abutment options: in number 1, the joint between components with an equal diameter. However, in the following examples it is modified (platform switching). In number 2 , the restoration diameter is reduced and in number 3, the implant platform is expanded, mathing implant and abutment diameter.

\section{Material and Methods}

The present study offers a review of the literature dealing with the impact of reducing the diameter of the platform on the oral hard and soft tissues. To this effect, a Medline search was carried out, using the PubMed search engine with the key words "platform switching", "expanded platform", "dental implant", "crestal bone preservation", "non-matching" and "abutment", as well as combinations of these key words. No limit in time was used in this search.

Inclusion criteria were papers published in journals indexed in MedLine in which modified platforms in dental implants are studied (platform switching concept), using different surgical techniques and clinical situations (immediate loading, delayed loading). As exclusion criteria, papers written in other languages were not used in our work. Only articles written in english were included.

\section{Results}

The first Medline publications on platform switching appeared in the year 2005, and since then over 30 articles have been published. All them have been included to perform this bibliographic revision.

Mostly of these studies are clinical cases or single clinical cases, 16 in total. In addition, we found 10 nonexperimental tests and control studies, 9 experimental studies ( 2 of them are histomorphometrical models in animals and 7 finite element analyses) and only 3 articles are literature review.

\section{Discussion}

The results described by the different authors are mostly encouraging. In the last 5 years, these results have led many researchers to become interested in these studies and to perform investigations. Also dental implants with integrated platform-switching designs have been commercialized.

The principal aspects of the consulted articles refer to biomechanical behavior of the abutment-implant complex in response to occlusal loading, bone crest level preservation and biological space repositioning.

For this reason, in the study, the authors consider each aspect individually and the text is divided into three parts.

\section{Biomechanical Behavior}

The close relationship between the bone and the implant is the essence of osteointegration. The bone changes occurring at the margins adjacent to the dental implants have been the subject of many clinical and experimental studies (8).

In turn, many hypotheses have been proposed in relation to the physiological processes that intervene in crestal bone stabilization. Although the etiological factors 
underlying bone loss have not been fully established (9), the main causal factors of crestal bone loss are occlusal overload and peri-implantitis (10). Characteristics such as implant design, crestal bone geometry and the location within the oral cavity must be taken into consideration for the optimum support and distribution of occlusal loading forces to the bone components (11).

Biomechanical studies of dental implants using finite elements analysis software are increasingly common (11-14). Such analyses are used by engineers to simulate loading situations involving different materials. This type of software helps to calculate stress and pressure within solid bodies, determining force transmission between different elements and their loading relationships (14).

In 2009, Hsu et al. analyzed the behavior of reduced platform restorations in the context of a finite elements study in three dimensions. Their results showed a $10 \%$ decrease in all the prosthetic loading forces transmitted to the bone-implant interface (15).

Similar finite elements studies in two dimensions show great variability in the results obtained. In effect, while some investigators report a decrease in force to the cortical bone of less than $10 \%$ (12), other authors such as Tabata et al. have reported a decrease of $80 \%$ (13).

Rodriguez-Ciurana et al. (14), in a two-dimensional biomechanical study involving platform switching integrated into the implant design, failed to obtain peri-implant bone force attenuation values as high as those reported in earlier studies, when comparing platform expansion with a traditional restoration model. In addition, the authors concluded that force dissipation in the platform switching restoration is slightly more favorable in an internal than in an external junction, since it improves distribution of the loads applied to the occlusal surface of the prosthesis along the axis of the implant.

On the other hand, this concentration of forces along the axis of the implant, transmitted through the retention screw, increases the possibility of abutment fracture, and thus may lead to failure of the global restoration (13).

All studies contrasting platform switching versus continuity of the platform with the body of the implant agree that force to bone diffusion is improved by expanding the platform. However, Canay and Akça (10), in a threedimensional finite elements analysis involving different implant-free expanded platform dimensions and a range of abutment designs, claimed that the effect of platform expansion is not attributable to the distribution of loads to the peri-implant bone but rather simply to redistribution of the new biological space. Nevertheless, the authors pointed to the need for further research on the behavior of the marginal bone around the implants.

The most appropriate reduced platform abutment design for securing lesser implant abutment material fatigue is represented by conical emergence abutments with a variable height of $1.5-2 \mathrm{~mm}$, freeing extension of the implant platform between $0.5-0.75 \mathrm{~mm}$ (10).

Such platform switching is not advisable in mandibular implant-mucosal support prostheses, since reduction of the diameter of the junction lessens the abutment resistance in response to occlusal loading applied in the posterior area of the overdentures - fundamentally compromising the connecting abutment closest to the area where loading is applied (16).

\section{Influence Upon Bone Crestal Level}

Crestal bone loss around dental implants has been frequently documented in recent years. However, the factors implicated in the bone reabsorption and appositioning mechanisms in implant treatment are not fully clear (17).

The widely accepted factors that attempt to explain the changes in bone height that occur after functional and aesthetic implant-supported restoration include the gingival biotype, the distance of the implant-abutment junction (IAJ) from the bone crest, repositioning of the gingival inflammatory infiltrate, and the distribution of forces in the portion of the implant in contact with the cortical bone $(13,18)$. Additional factors are loss secondary to aggression such as mucoperiosteal flap raising, second-stage surgery for exposing the screw, and colonization by bacteria belonging to the oral flora at the coronal bone and implant junction $(17,19)$. Other authors have also studied crestal bone loss and its relationship to the facial bone thickness of the patient (20).

In numerical terms, bone loss in two-stage implantsupported restorations is estimated to be $1.5-2 \mathrm{~mm}$ below the implant-abutment junction, exposing one or two threads after one year supporting a prosthetic restoration. In general, this exposure of the implant body is not regarded as a sign of failure (20).

However, in the studies on platform switching involving a follow-up period of 4-169 months, the reported bone loss varies between 0.05-1.4 mm (Table 1) (21).

Despite these findings in the literature, some investigators consider platform expansion to be of key importance for crestal bone stability. Experimental histomorphometric studies have shown improvement in crestal bone levels in abutments with platform reduction, though statistical significance was not reached $(18,22)$.

In 2009, Prosper et al., in a multicenter study of $360 \mathrm{im}-$ plants, compared expanded platforms versus cylindrical implants involving abutments of the same size, placed in 60 partially edentulous patients (9). The results showed a lesser percentage bone loss on employing the reduced platforms, with the preservation of up to $98.3 \%$ versus $66.1 \%$ after 12 months, and $97.2 \%$ versus $53.3 \%$ with the standard platform after two years.

Platform reduction with immediate functional loading 
Table 1. Bone preservation, number of implants placed, and follow-up according to the studies found in the Medline search of dental implant platform switching in humans subjects.

\begin{tabular}{|c|c|c|c|c|c|}
\hline Author & $\begin{array}{l}\text { Crestal bone } \\
\text { loss }(\mathrm{mm})\end{array}$ & $N^{0}$ implants & $\begin{array}{c}\text { Follow- } \\
\text { up(months) }\end{array}$ & $\begin{array}{c}\text { Study } \\
\text { Caracteristics }\end{array}$ & $\begin{array}{c}\text { Surgical } \\
\text { Caracteristics }\end{array}$ \\
\hline $\begin{array}{l}\text { Wagenberg \& } \\
\text { Froum } 2010(18)\end{array}$ & $0,33-0,31$ & 94 & $132-169$ & Clinical cases & $\begin{array}{l}\text { Two stage surgical } \\
\text { protocol }\end{array}$ \\
\hline $\begin{array}{l}\text { Prosper et al. } 2010 \\
(25)\end{array}$ & $0,51-1,16$ & $116($ total 120$)$ & 60 & Clinical cases & $\begin{array}{l}\text { Immediate and delayed } \\
\text { loading }\end{array}$ \\
\hline $\begin{array}{l}\text { Cocchetto et al. } \\
2010(29)\end{array}$ & $0,05-1,63$ & 15 & 18 & Clinical cases & $\begin{array}{l}\text { One step surgical } \\
\text { protocol (one post- } \\
\text { extraction implant) }\end{array}$ \\
\hline $\begin{array}{l}\text { Bilhan et al. } 2010 \\
\text { (26) }\end{array}$ & $0,91-0,89$ & 126 & 36 & Clinical cases & $\begin{array}{l}\text { Two steps surgical } \\
\text { protocol }\end{array}$ \\
\hline $\begin{array}{l}\text { Canullo et al. } 2010 \\
\text { (32) }\end{array}$ & 0,83 & 44 (total 60) & 33 & $\begin{array}{l}\text { Test and control } \\
\text { group multicenter }\end{array}$ & $\begin{array}{l}\text { Two steps surgical } \\
\text { protocol }\end{array}$ \\
\hline $\begin{array}{l}\text { Trammel et al. } \\
2009(40)\end{array}$ & $0,99 \pm 0,53$ & 25 & 24 & $\begin{array}{l}\text { Test and control } \\
\text { group }\end{array}$ & $\begin{array}{l}\text { One step surgical } \\
\text { protocol }\end{array}$ \\
\hline $\begin{array}{l}\text { Canullo et al. } \\
2009(28)\end{array}$ & $0,47-0,36$ & 22 & 25 & $\begin{array}{l}\text { Clinical cases } \\
\text { multicenter }\end{array}$ & $\begin{array}{l}\text { Inmediate post- } \\
\text { extraction restoration }\end{array}$ \\
\hline $\begin{array}{l}\text { Rodriguez- } \\
\text { Ciurana et al. } \\
2009 \text { (14) }\end{array}$ & $0,59-0,6$ & 82 & 15 & $\begin{array}{l}\text { Clinical cases, } \\
\text { multicenter }\end{array}$ & $\begin{array}{l}\text { Two stage surgical } \\
\text { protocol }\end{array}$ \\
\hline $\begin{array}{l}\text { Prosper et al. } 2009 \\
\text { (9) }\end{array}$ & $0,05-0,23$ & $180($ total 360$)$ & 24 & $\begin{array}{l}\text { Test and control } \\
\text { group }\end{array}$ & $\begin{array}{l}\text { One-step and two step } \\
\text { surgical protocol }\end{array}$ \\
\hline $\begin{array}{l}\text { Calvo-Guirado et } \\
\text { al. } 2009(5)\end{array}$ & $0,08-0,09$ & 59 & 12 & Clinical cases & $\begin{array}{l}\text { Inmediate funcional } \\
\text { loading }\end{array}$ \\
\hline $\begin{array}{l}\text { Cappiello et al. } \\
2008(21)\end{array}$ & $0,95 \pm 0,32$ & $75($ total 131$)$ & 12 & $\begin{array}{l}\text { Test and control } \\
\text { group }\end{array}$ & $\begin{array}{l}\text { One step surgical } \\
\text { protocol }\end{array}$ \\
\hline $\begin{array}{l}\text { Calvo-Guirado et } \\
\text { al. } 2008(30)\end{array}$ & 0,6 & 104 (Total 105) & 16 & Clinical cases & $\begin{array}{l}\text { Immediate loading and } \\
\text { immediate restauration }\end{array}$ \\
\hline $\begin{array}{l}\text { Hurzeler et al. } \\
2007 \text { (37) }\end{array}$ & $0,12 \pm, 40$ & 148 (Total 22) & 12 & $\begin{array}{l}\text { Test and control } \\
\text { group }\end{array}$ & $\begin{array}{l}\text { Two stage surgical } \\
\text { protocol }\end{array}$ \\
\hline $\begin{array}{l}\text { Canullo \& } \\
\text { Rasperini } 2007 \\
(39)\end{array}$ & $0,78 \pm 0,36$ & 10 & 22 & Clinical cases & $\begin{array}{l}\text { Inmediate post- } \\
\text { extraction restoration }\end{array}$ \\
\hline $\begin{array}{l}\text { Calvo-Guirado et } \\
\text { al. } 2007 \text { (1) }\end{array}$ & $0,05-0,07$ & 10 & 6 & $\begin{array}{l}\text { Test and control } \\
\text { group }\end{array}$ & $\begin{array}{l}\text { Inmediate post- } \\
\text { extraction restoration }\end{array}$ \\
\hline $\begin{array}{l}\text { Vela-Nebot et al. } \\
2006(31)\end{array}$ & $0,76-0,77$ & 30 (Total de 60) & 6 & $\begin{array}{l}\text { Test and control } \\
\text { group }\end{array}$ & $\begin{array}{l}\text { One-step and two step } \\
\text { surgical protocol }\end{array}$ \\
\hline Garner 2005 (3) & $1,3-1,4$ & 1 & 4 & Clinical case & $\begin{array}{c}\text { Inmediate post- } \\
\text { extraction restoration }\end{array}$ \\
\hline
\end{tabular}


in the rehabilitation of edentulous arches has also been documented in the literature. The authors consider this design of the abutment-implant complex to be decisive for crestal bone stability in both non-smokers and smokers of more than two packs of cigarettes a day (23-26). There have also been reports of immediate post-extraction rehabilitation with very satisfactory results in terms of soft and hard tissue preservation. Platform expansion in post-extraction situations makes it possible to minimize the gap between the recently extracted tooth bed and the implant, acting as a physical barrier against the penetration of bacteria in the zone of contact between the bone and implant. This increase in diameter favors improved primary stability $(15,28-31)$.

\section{Soft Tissue Response}

Of the different theories proposed to explain maxillary bone remodeling after dental implant placement, the most widely studied has been the formation of a new biological space. The creation of this mechanical barrier serves as a defense mechanism, preventing the penetration of bacteria from the oral environment (32).

Such physiological sealing shows morphological differences according to whether it is formed in relation to a tooth or a dental implant. The biological space adjacent to an implant is greater than the space adjacent to a natural tooth, with histological differences in terms of the organization and distribution of the fibers. In addition to differences attributable to location, the biological space of an epicrestal implant forms at subcrestal level, while in the case of a natural tooth the space is formed at supracrestal level (33).

These differences in formation and morphology could be related to the corresponding vascular supply. In effect, while the soft tissues surrounding an implant are only vascularized by vessels from the periosteum, the tissues adjacent to natural teeth are also vascularized through the periodontal ligament (34).

Implant design also influences the morphology of the gingival margin - both the neck micro- and macrostructure, and the macrostructure of the implant-abutment junction. In turn, ensuring a minimum distance of 3 $\mathrm{mm}$ between implants allows sufficient margin to restore the biological space of both restorations, as demonstrated by Tarnow et al. a decade ago. In implants involving an expanded platform integrated in their macrostructure, and ensuring the above mentioned distance between implants, bone crest preservation is seen to be $57 \%$ greater than with a traditional restoration design (30, 35, 36).

According to Lazzara and Porter, the deliberate creation of a space for the mentioned physiological barrier minimizes the space for repositioning of the fibers. By displacing the junction with the abutment to a more medial position with respect to the axis, an increased surface area of the implant is freed - thus favoring controlled repositioning of the biological space $(37,38)$.

The space is created in the horizontal plane one millimeter from the implant-abutment junction, supported over the external margin of the platform. In addition, this procedure keeps the inflammatory infiltrate away from the crestal bone margin, with a $50 \%$ reduction in occupation surface $(38,39)$.

Trammell et al. (40), in a case-control study, measured the biological space with reduced and conventional platform abutments in the same individual. Although the mean biological width was similar in both groups (1.57 $\pm 0.72 \mathrm{~mm}$ with the expanded platform and $1.53 \pm 0.78$ $\mathrm{mm}$ with conventional abutments), bone loss was significantly smaller with the expanded platform.

\section{Conclusions}

All authors agree that the use of implants with platform switching improves bone crest preservation and leads to controlled biological space reposition. According to the different papers, this expanded platform obtains excellent aesthetic outcomes.

Due to the limited sample of human beings, and the small number of implants and follow ups, further clinical investigations are necessary to show long term results.

\section{References}

References with links to Crossref - DOI

1. Calvo Guirado JL, Saez Yuguero MR, Pardo Zamora G, Muñoz Barrio E. Immediate provisionalization on a new implant design for esthetic restoration and preserving crestal bone. Implant Dent. 2007; 16:155-64.

2. Priest GF. The esthetic challenge of adjacent implants. J Oral Maxillofac Surg. 2007;65:2-12.

3. Gardner DM. Platform switching as a means to achieving implant esthetics. N Y State Dent J. 2005;71:34-7.

4. Luongo R, Traini T, Guidone PC, Bianco G, Cocchetto R, Celletti R. Hard and soft tissue responses to the platform-switching technique. Int J Periodontics Restorative Dent. 2008;28:551-7.

5. Calvo-Guirado JL, Ortiz-Ruiz AJ, López-Marí L, Delgado-Ruiz R, Maté-Sánchez J, Bravo Gonzalez LA. Immediate maxillary restoration of single-tooth implants using platform switching for crestal bone preservation: a 12-month study. Int J Oral Maxillofac Implants. 2009;24:275-81.

6. Danza M, Riccardo G, Carinci F. Bone platform switching: a retrospective study on the slope of reverse conical neck. Quintessence Int. 2010;41:35-40

7. Carinci F, Brunelli G, Danza M. Platform switching and bone platform switching. J Oral Implantol. 2009;35:245-50.

8. Miyata T, Kobayashi Y, Araki H, Ohto T, Shin K. The influence of controlled occlusal overload on peri-implant tissue. Part 3: A histologic study in monkeys. Int J Oral Maxillofac Implants. 2000;15:42531.

9. Prosper L, Redaelli S, Pasi M, Zarone F, Radaelli G, Gherlone EF. A randomized prospective multicenter trial evaluating the platformswitching technique for the prevention of postrestorative crestal bone loss. Int J Oral Maxillofac Implants. 2009;24:299-308.

10. Canay S, Akça K. Biomechanical aspects of bone-level diameter shifting at implant-abutment interface. Implant Dent. 2009;18:23948 .

11. Baggi L, Cappelloni I, Di Girolamo M, Maceri F, Vairo G. The influence of implant diameter and length on stress distribution of os- 
seointegrated implants related to crestal bone geometry: a three-dimensional finite element analysis. J Prosthet Dent. 2008;100:422-31. 12. Schrotenboer J, Tsao YP, Kinariwala V, Wang HL. Effect of platform switching on implant crest bone stress: a finite element analysis. Implant Dent. 2009;18:260-9.

13. Tabata LF, Assunção WG, Adelino Ricardo Barão V, de Sousa EA, Gomes EA, Delben JA. Implant platform switching: biomechanical approach using two-dimensional finite element analysis. J Craniofac Surg. 2010;21:182-7.

14. Rodríguez-Ciurana $X$, Vela-Nebot $X$, Segalà-Torres $M$, RodadoAlonso C, Méndez-Blanco V, Mata-Bugueroles M. Biomechanical repercussions of bone resorption related to biologic width: a finite element analysis of three implant-abutment configurations. Int J Periodontics Restorative Dent. 2009;29:479-87.

15. Hsu JT, Fuh LJ, Lin DJ, Shen YW, Huang HL. Bone strain and interfacial sliding analyses of platform switching and implant diameter on an immediately loaded implant: experimental and three-dimensional finite element analyses. J Periodontol. 2009;80:1125-32.

16. Sabet ME, El-Korashy DI, El-Mahrouky NA. Effect of platform switching on strain developed around implants supporting mandibular overdenture. Implant Dent. 2009;18:362-70.

17. Hermann F, Lerner H, Palti A. Factors influencing the preservation of the periimplant marginal bone. Implant Dent. 2007;16:16575 .

18. Wagenberg B, Froum SJ. Prospective study of 94 platformswitched implants observed from 1992 to 2006. Int J Periodontics Restorative Dent. 2010;30:9-17.

19. Becker J, Ferrari D, Herten M, Kirsch A, Schaer A, Schwarz F. Influence of platform switching on crestal bone changes at non-submerged titanium implants: a histomorphometrical study in dogs. J Clin Periodontol. 2007;34:1089-96.

20. Spray JR, Black CG, Morris HF, Ochi S. The influence of bone thickness on facial marginal bone response: stage 1 placement through stage 2 uncovering. Ann Periodontol. 2000;5:119-28.

21. Cappiello M, Luongo R, Di Iorio D, Bugea C, Cocchetto R, Celletti R. Evaluation of peri-implant bone loss around platform-switched implants. Int J Periodontics Restorative Dent. 2008;28:347-55.

22. López-Marí L, Calvo-Guirado JL, Martín-Castellote B, GomezMoreno G, López-Marí M. Implant platform switching concept: an updated review. Med Oral Patol Oral Cir Bucal. 2009;14:e450-4.

23. Becker J, Ferrari D, Mihatovic I, Sahm N, Schaer A, Schwarz F. Stability of crestal bone level at platform-switched non-submerged titanium implants: a histomorphometrical study in dogs. J Clin Periodontol. 2009;36:532-9.

24. Romanos GE, Nentwig GH. Immediate functional loading in the maxilla using implants with platform switching: five-year results. Int J Oral Maxillofac Implants. 2009;24:1106-12.

25. Prosper L, Crespi R, Valenti E, Capparé P, Gherlone E. Five-year follow-up of wide-diameter implants placed in fresh molar extraction sockets in the mandible: immediate versus delayed loading. Int J Oral Maxillofac Implants. 2010;25:607-12.

26. Bilhan H, Mumcu E, Erol S, Kutay O. Influence of platformswitching on marginal bone levels for implants with mandibular overdentures: a retrospective clinical study. Implant Dent. 2010;19:250-8

27. Romanos GE, Nentwig GH. Immediate loading using cross-arch fixed restorations in heavy smokers: nine consecutive case reports for edentulous arches. Int J Oral Maxillofac Implants. 2008;23:513-9.

28. Canullo L, Iurlaro G, Iannello G. Double-blind randomized controlled trial study on post-extraction immediately restored implants using the switching platform concept: soft tissue response. Preliminary report. Clin Oral Implants Res. 2009;20:414-20.

29. Cocchetto R, Traini T, Caddeo F, Celletti R. Evaluation of hard tissue response around wider platform-switched implants. Int J Periodontics Restorative Dent. 2010;30:163-71.

30. Calvo Guirado JL, Ortiz Ruiz AJ, Gómez Moreno G, López Marí L, Bravo González LA. Immediate loading and immediate restoration in 105 expanded-platform implants via the Diem System after a 16-month follow-up period. Med Oral Patol Oral Cir Bucal. 2008;13:E576-81.

31. Vela-Nebot X, Rodríguez-Ciurana X, Rodado-Alonso C, SegalàTorres M. Benefits of an implant platform modification technique to reduce crestal bone resorption. Implant Dent. 2006;15:313-20.

32. Canullo L, Fedele GR, Iannello G, Jepsen S. Platform switching and marginal bone-level alterations: the results of a randomizedcontrolled trial. Clin Oral Implants Res. 2010;21:115-21.

33. Degidi M, Iezzi G, Scarano A, Piattelli A. Immediately loaded titanium implant with a tissue-stabilizing/maintaining design ('beyond platform switch') retrieved from man after 4 weeks: a histological and histomorphometrical evaluation. A case report. Clin Oral Implants Res. 2008;19:276-82.

34. Sorni-Bröker M, Peñarrocha-Diago $M$, Peñarrocha-Diago M. Factors that influence the position of the peri-implant soft tissues: a review. Med Oral Patol Oral Cir Bucal. 2009;14:e475-9.

35. Tarnow DP, Cho SC, Wallace SS. The effect of inter-implant distance on the height of inter-implant bone crest. J Periodontol. 2000;71:546-9.

36. Rodríguez-Ciurana X, Vela-Nebot X, Segalà-Torres M, CalvoGuirado JL, Cambra J, Méndez-Blanco V, Tarnow DP. The effect of interimplant distance on the height of the interimplant bone crest when using platform-switched implants. Int J Periodontics Restorative Dent. 2009;29:141-51.

37. Hürzeler M, Fickl S, Zuhr O, Wachtel HC. Peri-implant bone level around implants with platform-switched abutments: preliminary data from a prospective study. J Oral Maxillofac Surg. 2007 Jul;65(7 Suppl 1):33-9. Erratum in: J Oral Maxillofac Surg. 2008;66:2195-6. 38. Lazzara RJ, Porter SS. Platform switching: a new concept in implant dentistry for controlling postrestorative crestal bone levels. Int J Periodontics Restorative Dent. 2006;26:9-17.

39. Canullo L, Rasperini G. Preservation of peri-implant soft and hard tissues using platform switching of implants placed in immediate extraction sockets: a proof-of-concept study with 12- to 36-month follow-up. Int J Oral Maxillofac Implants. 2007;22:995-1000.

40. Trammell K, Geurs NC, O’Neal SJ, Liu PR, Haigh SJ, McNeal $\mathrm{S}$, et al. A prospective, randomized, controlled comparison of platform-switched and matched-abutment implants in short-span partial denture situations. Int J Periodontics Restorative Dent. 2009;29:599605 .

\section{Acknowledgement}

Authors wants to show their gratitude to Damian Serrano Sánchez for the implant platforms design didactic image. Contributing in an unselfish way. 